\title{
PREFERENSI KONSUMEN TERHADAP FURNITUR DI KOTA BANDA ACEH
}

(Consumer Preferences Towards Furniture In Banda Aceh City)

\author{
Dian Lutfiani ${ }^{1}$, Suyanti Kasimin ${ }^{1}$, Romano $^{1}{ }^{*}$ \\ ${ }^{1}$ Program StudiAgribisnis, FakultasPertanian, UniversitasSyiah Kuala
}

\begin{abstract}
Abstrak - Untuk tetap dapat mempertahankan pangsa pasar furnitur, maka pedagang harus menerapkan satu strategi untuk menarik minat konsumen membeli produk furnitur. Penelitian ini bertujuan untuk mengetahui pengaruh atribut produk terhadap preferensi konsumen Di Kota Banda Aceh. Metode penelitian yang digunakan yaitu metode survei dengan menggunakan kuisioner dan wawancara. Penentuan lokasi ini ditentukan dengan sengaja (purposive sampling). Populasi dalam penelitian ini adalah masyarakat konsumen furniture khususnya jenis jepara, rotan dan furnitur modern(tidak berbahan kayu jati dan rotan) dengan item kursi, meja dan tempat tidur yang berdomisili di Kota Banda Aceh. Teknik pengambilan sampel dilakukan dengan metode non probability sampling yaitu menggunakan sampling insidental dengan penarikan sampel secara kebetulan bertemu dengan peneliti serta dapat digunakan sebagai sampel, ditempat yang mudah dijangkau dan dianggap memenuhi syarat sebagai responden. Besarnya sampel dalam penelitian ini adalah sebanyak 90 responden. Masing- masing dari jenis-jenis furnitur diambil sebanyak 30. Analisis data yang digunakan adalah analisis regresi biner logistic. Berdasarkan hasil analisis, diperoleh nilai signifikansi dari variabel kualitas produk, desain dan harga lebih kecil dari nilai $\alpha=0,05$, yang menunjukkan bahwa variabel kualitas produk, desain dan harga mempengaruhi konsumen.
\end{abstract}

Kata Kunci : Preferensi konsumen, furnitur, kualitas produk, desain, harga

\begin{abstract}
To maintain the market share of furniture, then the trader must implement a strategy to attract consumers to buy furniture products. This study aims to know the effect of product attributes toward consumer preferences in banda aceh. The reserch method used is survey method which uses questionnaires and interviews. Determination of this location is determined by puroseful (purposive sampling). Population of this research is the consumer society furniture especially type of jepara, rattan and modern furniture (not made from teak wood and rattan) with items chair, table, and bed which are domiciled in Band Aceh. The sampling technique is done by non-probability sampling that uses incidental sampling to the withdrawal by chance met with researchers and can be used as a sample. in the place that is easiliy accessible and its qualified to be the respondent. The sample size in this study is as much as 90 respondents. Each types of furniture taken as much as 30. The Analysis of data which used is a binary logistic regression analysis. Based on the analysis, significance value of the variable quality of the products, the design and the cost is less than the value $\alpha$ score $=$ 0,05 , which indicates that the variable quality of the product, design and cost affect consumers.
\end{abstract}

Key words : Consumer preferency, furniture, quality of product, design, cost. 


\section{PENDAHULUAN}

Furnituradalah perabotan yang memiliki tempat untuk menyimpan sesuatu dengan posisi tetap atau memiliki tempat tertentu di dalam ruangan yang berdiri sendiri. Menurut Jamaludin (2007) dari segi fungsi atau peruntukan, furnitur terdiri dari 4 jenis yaitu tempat menyimpan sesuatu diatasnya, tempat menyimpan sesuatu didalamnya, tempat terlentang atau tidur dan tempat duduk. Pada saat ini kayu dimanfaatkan dalam pembuatan mebel. Mebel sebagai kebutuhan sekunder memiliki kecenderungan yang berbeda-beda menurut waktu, sehingga pada saat ini industri sekunder telah memasuki era teknologi tinggi.

Preferensi konsumen adalah pilihan suka atau tidak suka seseorang terhadap produk (barang atau jasa) yang dikonsumsi. Preferensi konsumen menunjukkan kesukaan konsumen dari berbagai pilihan produk yang ada (Kotler ,1997). preferensi konsumen merupakan nilainilai yang dianut dan dipertahankan oleh konsumen. Dengan demikian preferensi merupakan gambaran-gambaran dari nilai-nilai terbaik yang dipertimbangkan konsumen dalam menentukan sebuah pilihan (Schifman dan Kanuk ,2000).

Menurut Sumarwan (2004), atribut produk adalah karakteristik dari suatu produk yang menjadi pertimbangan konsumen dalam membeli suatu produk.Berdasarkan pada hal ini, konsumen sebagai obyek penawaran yang harus selalu diperhatikan. Perusahaan harus mampu menganalisa kepuasan konsumen, karena pada akhirnya, konsumen lah yang akan menentukan tepat atau tidaknya kualitas sebuah produk tersebut. Perusahaan juga harus memperhatikan pandangan konsumen terhadap kualitas produk dan bagaimana pandangan konsumen tersebut dapat mempengaruhi keputusan konsumen. Pandangan konsumen terhadap atribut produk lah yang merupakan penilaian menyeluruh atas keunggulan suatu produk (Saputra dan Suprihadi, 2013).

Berdasarkan latar belakang yang telah diuraikan di atas tujuan penelitian ini adalah untuk mengetahuiuntuk mengetahui pengaruh atribut produk terhadap preferensi konsumen pada furnitur di Kota Banda Aceh.

\section{METODOLOGI PENELITIAN}

Penelitian ini dilaksanakan di Kota Banda Aceh. Pemilihan lokasi ini dilakukan secara sengaja (Purposive Sampling) dengan pertimbangan Kota Banda Aceh merupakan salah satu wilayah yang memiliki potensi strategis untuk pemasaran produk jepara, rotan dan furnitur modern(tidak berbahan kayu jati dan rotan) di Provinsi Aceh, dan dengan berdasarkan toko usaha furnitur yang memiliki industri pembuatan furnitur dan memiliki outlet sendiri untuk produk jepara dan rotan sedangkan furnitur modern(tidak berbahan baku kayu jati dan rotan) berdasarkan terletak dipusat kota Banda Aceh.

Lokasi penelitian dilakukan di beberapa tempat pembuatan dan penjualan produk furnitur jepara dan rotan di wilayah Kota Banda Aceh yaitu Toko Esa Jepara, David Jepara, Karya Indah Jepara, Rattan Furnitur, Karya Trieng, Rotan Indah,dan untuk furnitur modern(tidak berbahan kayu jati dan rotan) di Sejati Meubel, Bina Baru Furnitur dan Cahaya Meubel .

Populasi dalam penelitian ini adalah masyarakat konsumen furnitur / mebel khususnya jenis jepara, rotan dan furnitur modern(tidak berbahan kayu jati dan rotan) dengan item kursi, meja dan tempat tidur yang berdomisili di Kota Banda Aceh. Adapun objek dalam penelitian ini adalah konsumen yang membeli dan memiliki produk furnitur yang berdomisili di Kota Banda Aceh. Sedangkan ruang lingkup penelitian ini hanya terbatas pada preferensi konsumen terhadap furnitur di Kota Banda Aceh. 
Teknik pengambilan sampel dilakukan dengan metode non probability sampling yaitu menggunakan sampling insidental dengan penarikan sampel secara kebetulan bertemu dengan peneliti serta dapat digunakan sebagai sampel, ditempat yang mudah dijangkau dan dianggap memenuhi syarat sebagai responden. Besarnya sampel dalam penelitian ini adalah sebanyak 90 responden. Masing- masing dari jenis-jenis furnitur diambil sebanyak 30 responden dengan total penelitian dari jenis-jenis furnitur sebanyak 3 jenis. Jumlah sampel sebesar 90 dipilih karena jumlah populasi yang tidak diketahui besarnya.

Penelitian ini merupakan analisis kuantitatif dan kualitatif deskriptif, yaitu data yang dikumpulkan melalui kuisioner kemudian diolah dengan alat analisis tabulasi deskriptif. Metode deskriptif adalah metode yang meneliti status kelompok manusia, suatu obyek, suatu set kondisi, suatu system pemikiran ataupun suatu kelas peristiwa pada masa sekarang.

Untuk pemberian skor berdasarkan tingkatan jawaban yang akan diterima dari responden maka digunakan metode Scoring, yaitu memakai skala pengukuran likert. Sedangkan untuk pengujian kuisioner memakai uji validitas dan uji realibilitas. Dan untuk menguji hipotesis memakai metode regresi biner logistik.

\section{HASIL DAN PEMBAHASAN}

Karakteristik Responden Berdasarkan Jenis Kelamin Usia, Pendidikan, Pekerjaan dan Penghasilan.

Berdasarkan Tabel 1, terlihat bahwa jumlah responden terbanyak adalah wanita dengan jumlah 78 orang atau sebesar $87 \%$ dikarenakan lebih banyak konsumen perempuan yang datang untuk membeli produk furnitur dibandingkan jumlah responden laki-laki yang hanya sebanyak 12 orang atau sebesar $13 \%$. Kegiatan untuk membeli perabot rumah tangga biasanya dilakukan oleh kaum perempuan dimana kaum perempuan lebih mengerti tentang produk furnitur yang akan memenuhi kebutuhan rumah tangganya dibandingkan kaum lakilaki. Ada beberapa untuk konsumen laki-laki mereka datang ke toko untuk membeli perlengkapan isi kamar untuk menikah dan selain itu seringnya kaum laki-laki menemani isteri atau calon isterinya untuk memilih produk furnitur.

Tabel 1. Karakteristik Responden yang Membeli dan Memiliki Produk Furnitur Berdasarkan Jenis Kelamin, Usia, Pendidikan, Pekerjaan dan Penghasilan Tahun 2016.

\begin{tabular}{|l|l|l|l|}
\hline No & \multicolumn{1}{|c|}{ Uraian } & \multicolumn{1}{|c|}{ Jumlah } & \multicolumn{1}{|c|}{ Persentase (\%) } \\
\hline 1 & Jenis Kelamin & & 13 \\
\hline a & Laki-laki & 12 & 87 \\
\hline b & Perempuan & 78 & 100 \\
\hline & Jumlah & 90 & \\
\hline & Rata-rata & Perempuan & Presentase (\%) \\
\hline 2 & Usia & Jumlah & 14 \\
\hline a & $21-25$ Tahun & 13 & 30 \\
\hline b & $26-30$ Tahun & 27 & \\
\hline
\end{tabular}




\begin{tabular}{|c|c|c|c|}
\hline $\mathrm{c}$ & 31 - 35 Tahun & 28 & 31 \\
\hline \multirow[t]{3}{*}{$\mathrm{d}$} & $>36$ Tahun & 22 & 24 \\
\hline & Jumlah & 90 & 100 \\
\hline & Rata-rata & $31-35$ & \\
\hline 3 & Pendidikan & Jumlah & Persentase $(\%)$ \\
\hline $\mathrm{a}$ & SMA & 20 & 22 \\
\hline $\mathrm{b}$ & S1 & 40 & 45 \\
\hline \multirow[t]{3}{*}{$\mathrm{c}$} & Lainnya & 30 & 33 \\
\hline & Jumlah & 90 & 100 \\
\hline & Rata-rata & S1 & \\
\hline 4 & Pekerjaan & Jumlah & Persentase $(\%)$ \\
\hline $\mathrm{a}$ & Karyawan Swasta & 24 & 27 \\
\hline $\mathrm{b}$ & PNS & 31 & 34 \\
\hline $\mathrm{c}$ & Wiraswasta & 28 & 31 \\
\hline $\mathrm{d}$ & Lainnya & 7 & 8 \\
\hline \multirow[t]{2}{*}{$\mathrm{e}$} & Jumlah & 90 & 100 \\
\hline & Rata-rata & PNS & \\
\hline 5 & Penghasilan( Rp / bulan) & Jumlah & Persentase (\%) \\
\hline $\mathrm{a}$ & $\operatorname{Rp} 1.000 .000-\operatorname{Rp} 2.000 .000$ & 11 & 12 \\
\hline $\mathrm{b}$ & $\operatorname{Rp} 2.000 .000-\operatorname{Rp} 3.000 .000$ & 34 & 38 \\
\hline $\mathrm{c}$ & $\operatorname{Rp} 3.000 .000-\operatorname{Rp} 4.000 .000$ & 35 & 39 \\
\hline $\mathrm{d}$ & $>\operatorname{Rp} 4.000 .000$ & 10 & 11 \\
\hline \multirow[t]{2}{*}{$\mathrm{e}$} & Jumlah & 90 & 100 \\
\hline & Rata-rata & $\begin{array}{l}\operatorname{Rp} 3.000 .000- \\
\operatorname{Rp} 4.000 .000\end{array}$ & \\
\hline
\end{tabular}

Sumber : Data Primer (diolah)2016

Pada penelitian ini yang paling dominan dalam mengkonsumsi berdasarkan tabel diatas dapat dilihat karakteristik responden yang berkepentingan mengkonsumsi produk furnitur 
didominasi pada usia 31-35 tahun atau 31\% dari seluruh responden. Pada usia antara $31-35$ tahun merupakan umur yang masih produktif dan masih memiliki jiwa untuk memikirkan kebutuhan perabot rumah tangga selain itu pada usia yang terpaut matang ini juga memiliki fnansial yang cukup ini terkait dengan pendapatan yang diperoleh.

Berdasarkan tabel diatas tingkat pendidikan terakhir, rata-rata responden telah menempuh pendidikan S1 (sarjana) sebanyak 40 orang atau 45\%, kemudian dilanjutkan dengan pendidikan lainnya yaitu diploma dan S2 sebanyak 30 orang atau 33\%, dan yang terakhir diikuti dengan pendidkan Sekolah Menengah Atas sebanyak 20 orang atau 22\%. Semakin tinggi tingkat pendiidkan seseorang maka tingkat pengetahuan terhadap informasi produk furnitur akan lebih baik.

Dilhat dari sisi pekerjaan yang menjadi mata pencaharian responden membeli dan memiliki produk furnitur di Banda Aceh posisi pertama terdapat responden yang bekerja sebagai Pegawai Negeri Sipil (PNS) yaitu sebanyak 31 orang atau 34\%, kemudian dilanjutkan dengan pekerjaan wiraswasta sebanyak 28 orang atau $31 \%$, seterusnya ditempati pekerja sebagai karyawan swasta sebanyak 24 orang atau $27 \%$, dan yang terakhir yaitu pekerjaan lainnya seperti ibu rumah tangga sebanyak 7 orang atau $8 \%$. Dari jenis pekerjaan telah diuraikan maka responden yang memiliki pekerjaan bagus akan memliki kecukupan finansial secara materi sehingga mereka dapat memenuhi kebutuhan hidupnya.

Minat konsumen erat kaitannya dengan penghasilan individu pada aspek pendapatan dapat dilihat dari tabel di atas dijelaskan bahwa rata-rata jumlah penghasilan per bulan responden yang membeli dan memliki produk furnitur diatas $\mathrm{Rp} 1.000 .000$,- yaitu $\mathrm{Rp}$ 3.000.000,- sampai dengan Rp 4.000.000,-. Maka dapat dilihat sebagian besar pendapatan yang dimiliki responden bisa mencukupi kebutuhan sekunder. Jenis furnitur yang di konsumsi konsumen terhadap jenis rotan, sofa dan jepara masing- masing 1 unit untuk setiap item kursi tamu, meja makan dan tempat tidur. Untuk harga furnitur beragam dari beberapa item kursi tamu, meja makan dan tempat tidur, harga yang paling tertinggi dari semua item yaitu jenis jepara.

\section{Tanggapan Konsumen Terhadap Preferensi Konsumen, Kualitas, Desain dan Harga Terhadap Furnitur Di Kota Banda Aceh}

Preferensi konsumen merupakan kecenderungan konsumen untuk memilih suatu produk lain. Pada penelitian ini preferensi yang dimaksud adalah preferensi terhadap beragam jenis furnitur yaitu rotan, sofa (modern) dan jepara. Berdasakan hasil penelitian konsumen menyukai dan menyetujui beberapa aspek sebagai preferensi konsumen terhadap furnitur di Kota Banda Aceh dapat dilihat pada Tabel 2.

Ada 3 aspek yang diukur pada preferensi konsumen furnitur yaitu kualitas, desain dan harga. Pada hasil rata-rata bahwa aspek desain yang mempengaruhi preferensi konsumen dengan nilai rata-rata 4,33. Pada produk furnitur konsumen lebih mengutamakan desain karena ini adalah kebutuhan sekunder yang memang tidak selalu di konsumsi. Kemudian pada aspek desain konsumen menyukai desain yang elegan, mewah, modern, antik dan unik. Kemudian pada aspek harga konsumen menyukai harga yang sesuai, untuk masalah harga ketika konsumen sudah menyukai dan mampu memenuhi keinginannya maka konsumen akan tetap memilih produk tersebut. Dan terakhir pada aspek kualitas konsumen beranggapan bahwa produk furnitur dirancang dengan bagus dari segi kualitas karena ini produk yang besar untuk digunakan untuk keperluan rumah tangga. Preferensi konsumen terhadap produk furnitur dipengaruhi yang pertama pada aspek desain yaitu 4,33, kemudian harga yaitu 4,26 dan yang terakhir kualitas yaitu 4,13. 
Tabel 2. Preferensi Konsumen Berdasarkan Jenis Produk

\begin{tabular}{|c|c|c|c|}
\hline No & Uraian & Nilai Preferensi & Preferensi Terbaik \\
\hline 1 & Kualitas & & \\
\hline & a. Rotan & 4,00 & \multirow{3}{*}{ Sofa $=4,40$} \\
\hline & b. Sofa & 4,40 & \\
\hline & c. Jepara & 4,00 & \\
\hline & Rata-rata & 4,13 & \\
\hline \multirow[t]{5}{*}{2} & Desain & & \\
\hline & a. Rotan & 4,40 & \multirow{3}{*}{ Rotan dan Sofa $=4,40$} \\
\hline & b. Sofa & 4,40 & \\
\hline & c. Jepara & 4,20 & \\
\hline & Rata-rata & 4,33 & \\
\hline \multirow[t]{5}{*}{3} & Harga & & \\
\hline & a. Rotan & 4,30 & \multirow{3}{*}{ Sofa $=4,40$} \\
\hline & b. Sofa & 4,40 & \\
\hline & c. Jepara & 4,10 & \\
\hline & Rata-rata & 4,26 & \\
\hline
\end{tabular}

Sumber : Data Primer (diolah) 2016

\section{Proses Keputusan Pembelian Pada Produk Furnitur}

a. Pengenalan Kebutuhan

Kebutuhan adalah segala sesuatu yang dibutuhkan manusia untuk mempertahankan hidup serta untuk memperoleh kesejateraan dan kenyamanan. Sedangkan keinginan adalah segala sesuatu yang kita miliki namun jika tidak mendapatkannya maka tidak mengganggu kelangsungan hidupnya. Dan dorongan yaitu merupakan kekuatan psikis yang berfungsi untuk mengarahkan perilaku manusia agar lebih fokus mencapai tujuannya.

Ada 3 aspek yang diukur pada pengenalan kebutuhan furnitur yaitu kebutuhan, keinginan dan dorongan. Responden yang memang membutuhkan produk furnitur untuk 
perlengkapan rumah tangga dapat dihitung dengan rata-rata jumlah responden dapat dilihat pada lampiran 7a, dari ketiga pengenalan kebutuhan maka alasan konsumen memilih furnitur dikarenakan kebutuhan dengan nilai 4,20 kemudian keinginan dengan nilai 4,00 dan dorongan dengan nilai 4,00. Diantara ketiga jenis produk furnitur maka kebutuhan produk yang paling berpengaruh pada jenis sofa.

Tabel 3. Pengenalan Kebutuhan Konsumen Terhadap Furnitur di Kota Banda Aceh.

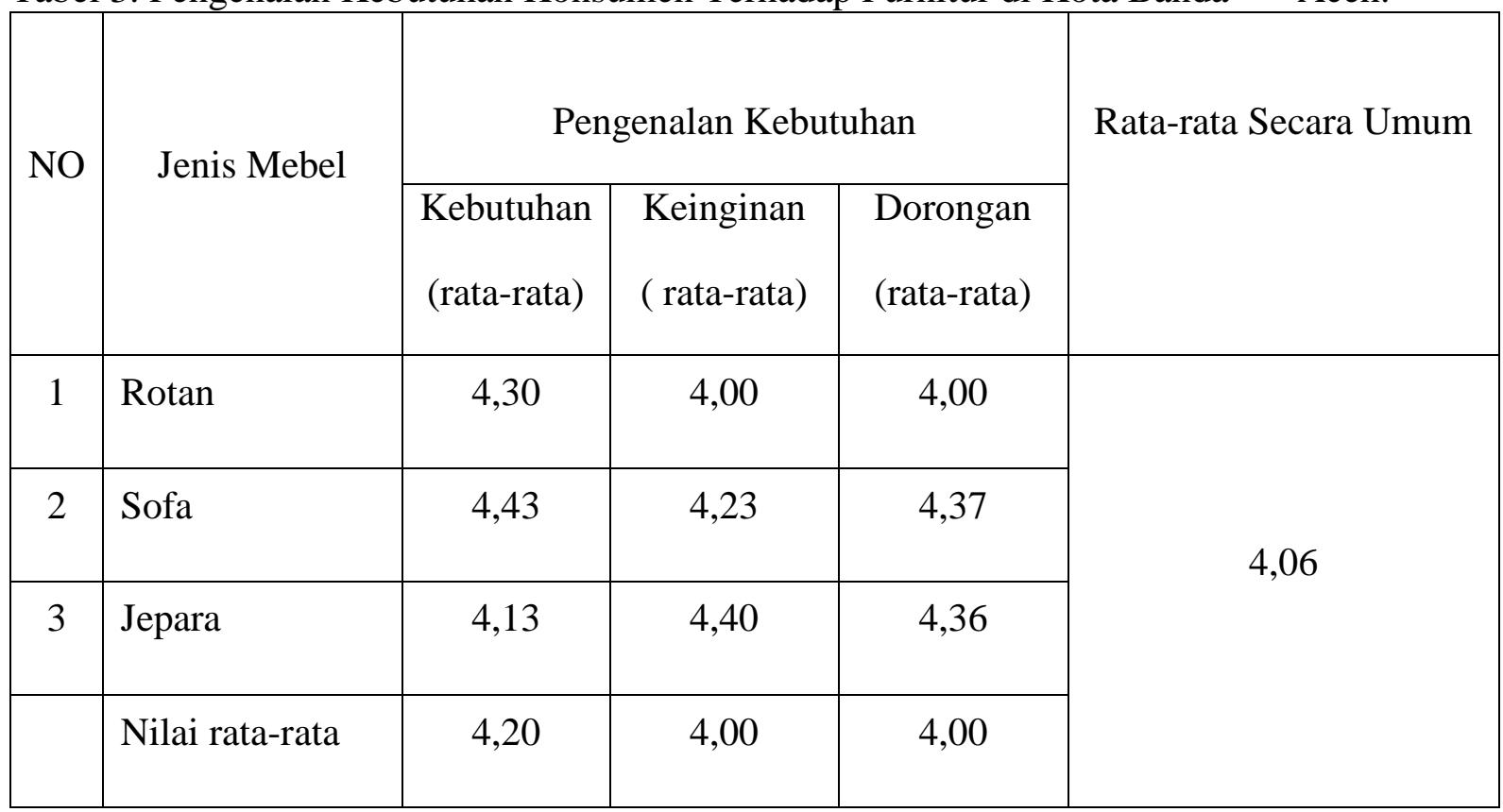

Sumber : Data Primer (diolah) 2016

Kebutuhan konsumen untuk membeli produk furnitur salah satunya untuk menambahkan perlengkapan produk yang baru pada suatu ruangan yang kosong atau kurangnya produk furnitur didalam nya. Atau menggantikan produk furnitur yang sudah rusak dan para konsumen lebih mengutamakan fungsi dari furnitur sesuai dengan kebutuhan. Adapun waktu konsumen untuk memenuhi kebutuhan tersebut salah satunya pada hari besar seperti Hari Raya Idul Fitri, Hari Natal dan sebagainya. Berdasarkan uraian diatas maka dapat disimpulkan bahwa sofa lebih unggul dibandingkan jepara dan rotan.

b. Sumber Informasi

Setelah melalui tahap pengenalan kebutuhan, selanjutnya konsumen akan mencari informasi mengenai produk furnitur yang akan dibelinya. Tahap ini dikenal dengan sebutan tahap pencarian informasi.

Ada 3 aspek yang diukur pada sumber informasi furnitur yaitu keluarga, media cetak dan media internet. Dari hasil penelitian bahwa dapat disimpulkan dari ketiga sumber informasi yang paling banyak diperoleh oleh konsumen furnitur berasal dari keluarga, teman atau kerabat. Bahwa sumber informasi yang diperoleh oleh konsumen furnitur berasal dari keluarga, teman atau kerabat dengan nilai rata- rata umum 4.38 yaitu pada jenis sofa. Produsen mengakui bahwa sumber informasi yang berasal dari keluarga, teman atau kerabat merupakan media informasi yang paling berpengaruh dalam usaha mempromosikan produk mereka.

Karena konsumen yang datang untuk membeli produk furnitur telah mengetahui produk tersebut dari keluarga, teman atau kerabat yang menjadi pelanggan toko tersebut. Tetapi tidak menutup kemungkinan bahwa konsumen bisa mendapakan informasi dari media cetak dan media elektronik seperti hasil penelitian diatas. Berdasarkan uraian diatas maka dapat disimpulkan bahwa sofa lebih unggul dibandingkan jepara dan rotan. 
Tabel 4. Sumber Informasi Konsumen Terhadap Furnitur di Kota Banda Aceh.

\begin{tabular}{|c|c|c|c|c|c|}
\hline \multirow{2}{*}{ No } & \multirow{2}{*}{ Jenis Mebel } & \multicolumn{3}{|c|}{ Sumber Informasi } & \multirow[b]{2}{*}{ Rata-Rata Secara Umum } \\
\hline & & $\begin{array}{l}\text { Keluarga } \\
\text { (rata-rata) }\end{array}$ & $\begin{array}{c}\text { Media } \\
\text { Cetak } \\
\text { (rata-rata) }\end{array}$ & $\begin{array}{c}\text { Media } \\
\text { Internet } \\
\text { (rata-rata) }\end{array}$ & \\
\hline 1 & Rotan & 4,36 & 4,00 & 4,30 & \multirow{4}{*}{4,26} \\
\hline 2 & Sofa & 4,43 & 4,40 & 4,36 & \\
\hline \multirow[t]{2}{*}{3} & Jepara & 4,36 & 4,00 & 4,30 & \\
\hline & Nilai rata-rata & 4,38 & 4,10 & 4,32 & \\
\hline
\end{tabular}

Sumber : Data Primer (diolah) 2016

c. Evaluasi Alternatif

Evaluasi alternatif dilakukan oleh konsumen, jika mereka telah memiliki informasi yang cukup jelas tentang hal-hal yang berhubungan dengan produk yang akan dibelinya. Pada tahap ini konsumen akan mendapatkan kriteria-kriteria yang relevan dengan keinginannya untuk dapat membuat suatu keputusan yang dirasa paling bermanfaat dalam memecahkan masalah yang di hadapi.

Tabel 5. Evaluasi Alternatif Konsumen Terhadap Furnitur di Kota Banda Aceh.

\begin{tabular}{|c|c|c|c|c|c|}
\hline \multirow{2}{*}{ No } & \multirow{2}{*}{ Jenis Mebel } & \multicolumn{3}{|c|}{ Evaluasi Alternatif } & \multirow[t]{2}{*}{ Rata-rata Secara Umum } \\
\hline & & $\begin{array}{l}\text { Kualitas } \\
\text { (rata-rata) }\end{array}$ & $\begin{array}{c}\text { Desain } \\
\text { (rata-rata) }\end{array}$ & $\begin{array}{c}\text { Harga } \\
\text { (rata-rata) }\end{array}$ & \\
\hline 1 & Rotan & 4,40 & 4,43 & 4,36 & \multirow{4}{*}{4,31} \\
\hline 2 & Sofa & 4,00 & 4,43 & 4,36 & \\
\hline 3 & Jepara & 4,40 & 4,30 & 4,36 & \\
\hline & Rata-rata & 4,20 & 4,38 & 4,36 & \\
\hline
\end{tabular}

Sumber : Data Primer (diolah) 2016

Ada 3 aspek yang diukur pada evaluasi alternatif furnitur yaitu kebutuhan, keinginan dan dorongan. Sebagai tahap awal dalam memilih produk, konsumen akan menjadikan kriteria-kriteria yang telah ditetapkan sebagai bahan pertimbangan konsumen dalam memilih 
dan membeli produk furnitur. Faktor desain merupakan hal utama yang dipertimbangkan oleh konsumen di toko furnitur, dengan nilai rata-rata umum sebesar 4,38, pada harga 4,36 dan pada kualitas sebesar 4,20 yaitu pada jenis sofa. Setiap konsumen memiliki selera yang berbeda-beda ada konsumen menyukai produk yang mewah, unik, antik, klasik dan modern. Berdasarkan uraian diatas maka dapat disimpulkan bahwa sofa lebih unggul dibandingkan jepara dan rotan.

Maka dalam proses pengambilan keputusan pembelian dapat dilihat pada nilai rata-rata secara umum maka nilai aspek evaluasi alternatif lebih tinggi yaitu 4,31 kemudian pencarian informasi sebesar 4,26 dan yang terendah yaitu kebutuhan yaitu 4,06.

\section{Hasil Uji Validitas dan Realibilitas}

Uji validitas dan realibilitas dilakukan terhadap kuisisoner yang digunakan untuk melihat preferensi konsumen terhadap furnitur di Kota Banda Aceh, kuisioner terdiri dari 21 pertanyaan. Uji signifikansi dilakukan dengan membanding niai $r$ hitung dan $r$ tabel untuk degree of freedom $(\mathrm{df})=\mathrm{n}-2$, dalam hal ini $\mathrm{n}$ adalah jumlah sampel. Pada uji validitas dan realibilitas dalam penelitian ini jumlah sampel $(n)=90$ dan besarnya df dapat dihiitung $90-2$ $=88$ dengan tingakat signifikansi 5\% maka nilai $\mathrm{r}$ tabelnyan adalah 0,2084. Hasil uji validitas dapat dilihat pada tabel berikut :

Tabel 6. Hasil uji Validitas

\begin{tabular}{|c|c|c|c|c|}
\hline Variabel & Pertanyaan & $r$ tabel & r Hitung & Keterangan \\
\hline \multirow{2}{*}{ Kualitas Produk } & 1 & \multirow{14}{*}{0,207} & 0,876 & Valid \\
\hline & 2 & & 0,834 & Valid \\
\hline \multirow{4}{*}{ Desain Produk } & 3 & & 0.651 & Valid \\
\hline & 4 & & 0,667 & Valid \\
\hline & 5 & & 0,565 & Valid \\
\hline & 6 & & 0,651 & Valid \\
\hline \multirow{3}{*}{ Harga Produk } & 7 & & 0,818 & Valid \\
\hline & 8 & & 0,573 & Valid \\
\hline & 9 & & 0,630 & Valid \\
\hline \multirow{3}{*}{ Preferensi Konsumen } & 10 & & 0,756 & Valid \\
\hline & 11 & & 0,732 & Valid \\
\hline & 12 & & 0,732 & Valid \\
\hline \multirow{2}{*}{$\begin{array}{l}\text { Pengenalan } \\
\text { Kebutuhan }\end{array}$} & 13 & & 0,866 & Valid \\
\hline & 14 & & 0,814 & Valid \\
\hline
\end{tabular}




\begin{tabular}{|c|c|c|c|}
\hline & 15 & 0,862 & Valid \\
\hline \multirow{3}{*}{ Pencarian Informasi } & 16 & 0,812 & Valid \\
\hline & 17 & 0,887 & Valid \\
\hline & 18 & 0,874 & Valid \\
\hline \multirow{3}{*}{ Evaluasi Alternatif } & 19 & 0,838 & Valid \\
\hline & 20 & 0,818 & Valid \\
\hline & 21 & 0,886 & Valid \\
\hline
\end{tabular}

Sumber : Data Primer (diolah) 2016

Dari tabel diatas dapat dilihat kuisioner yang digunakan sudah valid karena nilai $r$ hitung setiap item pertanyaan lebih besar dari nilai $r$ tabel. Sedangkan untuk hasil uji realibilitas kuisioner dapat dilihat pada tabel berikut :

Tabel 7. Hasil Uji Realibilitas Kuisioner

\begin{tabular}{|c|c|c|c|c|}
\hline Variabel & Pertanyaan & $\mathrm{r}$ tabel & Croanbach & Keterangan \\
\hline \multirow{2}{*}{$\begin{array}{l}\text { Kualitas } \\
\text { Produk }\end{array}$} & 1 & \multirow{15}{*}{0,207} & \multirow{2}{*}{0,764} & \multirow{2}{*}{ Reliable } \\
\hline & 2 & & & \\
\hline \multirow{4}{*}{$\begin{array}{l}\text { Desain } \\
\text { Produk }\end{array}$} & 3 & & \multirow{4}{*}{0,720} & \multirow{4}{*}{ Reliable } \\
\hline & 4 & & & \\
\hline & 5 & & & \\
\hline & 6 & & & \\
\hline \multirow{3}{*}{ Harga Produk } & 7 & & \multirow{3}{*}{0,679} & \multirow{3}{*}{ Reliable } \\
\hline & 8 & & & \\
\hline & 9 & & & \\
\hline \multirow{3}{*}{$\begin{array}{l}\text { Preferensi } \\
\text { Konsumen }\end{array}$} & 10 & & \multirow{3}{*}{0,807} & \multirow{3}{*}{ Reliable } \\
\hline & 11 & & & \\
\hline & 12 & & & \\
\hline \multirow{3}{*}{$\begin{array}{l}\text { Pengenalan } \\
\text { Kebutuhan }\end{array}$} & 13 & & \multirow{3}{*}{0,843} & \multirow{3}{*}{ Reliable } \\
\hline & 14 & & & \\
\hline & 15 & & & \\
\hline
\end{tabular}




\begin{tabular}{|l|c|c|c|c|}
\hline \multirow{2}{*}{$\begin{array}{l}\text { Pencarian } \\
\text { Informasi }\end{array}$} & 16 & & 0,849 & Reliable \\
\cline { 2 - 2 } & 18 & & & \\
\cline { 2 - 2 } & 19 & & & Reliable \\
\cline { 2 - 2 } $\begin{array}{l}\text { Evaluasi } \\
\text { Alternatif }\end{array}$ & 20 & & 0,845 & \\
\cline { 2 - 2 } & 21 & & & \\
\hline
\end{tabular}

Sumber : Data Primer (diolah) 2016

Dari tabel diatas dapat diketahui bahwa kuisioner yang digunakan sudah reliable atau konsisten karena nilai Cronbach Alpha $(\alpha)>\mathrm{r}$ tabel. Uji validitas dan realibilitas yang digunakan sudah berdasarkan dasar pengambilan keputusannya masing-masing.

\section{Preferensi Konsumen terhadap Furnitur di Kota Banda Aceh}

Berdasarakan hasil analisis regresi biner logistic terhadap 90 responden,inilah hasil dari regresi yang bisa dilihat pada tabel dibawah ini preferensi konsumen terhadap furnitur di Kota Banda Aceh sebagai berikut :

Tabel 8. Hasil Analisis Preferensi Konsumen Terhadap Furnitur Di Kota Banda Aceh Tahun 2016.

\begin{tabular}{|l|c|c|c|c|}
\hline \multicolumn{1}{|c|}{ Variabel } & Koefisien & Std. Error & Sig. & Exp (B) \\
\hline Kualitas produk (X1) & 0,848 & 0,393 & 0,031 & 2,335 \\
\hline Desain Produk (X2) & 2,274 & 1,068 & 0,033 & 9,722 \\
\hline Harga (X3) & 1,339 & 0,555 & 0,016 & 3,817 \\
\hline Constant & $-16,861$ & 5,987 & 0,005 & 0,000 \\
\hline
\end{tabular}

Sumber : Data Primer (diolah) 2016

Pada tabel diatas diketahui bahwa variabel independent yang berpengaruh signifikan (nyata) adalah kualitas produk (X1), desain (X2) dan harga (X3) produk furnitur karena memiliki nilai signifikansi lebih kecil dari $\alpha=0,05$. Maka dapat dilihat dari semua atribut produk yaitu kualitas, desain dan harga memiliki nilai koefisien positif yang berarti adanya pengaruh atribut produk terhadap preferensi. Nilai konstan pada koefisien yaitu -16,861 yang berarti jika nilai kualitas, desain dan harga sebesar nol (0) maka nilai furnitur dimata konsumen sebesar $-16,861$.

Nilai tersebut menunjukkan betapa pentingnya atribut produk pada furnitur. Setiap peningkatan 1 poin pada kualitas produk maka akan meningkatkan preferensi konsumen sebesar 2,335 kali, untuk desain setiap peningkatan 1 poin pada desain maka akan meningkatkan preferensi konsumen sebesar 9,722 kali dan setiap peningkatan 1 poin pada harga maka akan meningkatkan preferensi konsumen sebesar 3,817 kali. Urutan atribut produk yang sangat berpengaruh pada preferensi konsumen yaitu desain, harga dan kualitas. 


\section{KESIMPULAN DAN SARAN}

Berdasarkan hasil penelitian dan pembahasan maka dapat disimpulkan beberapa hal, yaitu preferensi konsumen pada ketiga produk jenis sofa, rotan dan jepara maka yang paling tinggi minat konsumen pada jenis sofa kemudian rotan dan yang terakhir jepara. Hal ini dikarenakan sofa memiliki desain yang modern sedangkan jepara memiliki nilai harga yang relatif tinggi. Diantara ketiga atribut maka aspek desain yang paling berpengaruh pada preferensi konsumen dalam memilih produk furnitur, kemudian harga dan terakhir kualitas.

Kualitas yang mempengaruhi konsumen memiliki nilai tertinggi pada daya tahan dan keawetan yaitu jenis jepara kemudian sofa dan terakhir rotan. Jepara terbuat dari kayu jati sehingga kekuatan produknya kokoh.Desain yang mempengaruhi konsumen memiliki nilai tertinggi pada aspek bentuk yaitu pada jenis sofa dan rotan. Sofa dan rotan memiliki bentuk yang beragam dan memiliki sifat modern dan unik.

Harga yang mempengaruhi konsumen memiliki nilai tertinggi pada harga yang sesuai desain yaitu pada jenis sofa. Harga yang ditetapkan pada sofa sesuai dengan desain yang diinginkan konsumen.Berdasarkan pengambilan keputusan pembelian maka pengenalan kebutuhan yang memiliki nilai tertinggi pada aspek kebutuhan yaitu pada jenis sofa kemudian keinginan dan terakhir dorongan. Hal ini disebabkan kebutuhan konsumen untuk membeli produk furnitur salah satunya untuk penambahan furnitur.Pencarian informasi yang dilakukan konsumen yaitu pada keluarga dalam jenis sofa dikarenakan konsumen lebih mudah untuk menanyakan dan mengetahui produk yang diminati. Kemudian pada media internet dan yang terakhir pada media cetak.Evaluasi alternatif yang dilakukan konsumen yaitu aspek desain pada jenis sofa kemudian harga dan yang terakhir kualitas.

Berdasarkan 3 jenis produk furnitur yang dibeli oleh konsumen maka pedagang sebaiknya lebih banyak menjual furnitur jenis sofa dibandingkan rotan dan jepara.Pedagang dalam memilih furnitur harus lebih memperhatikan desain yang menarik, harga jual yang tidak terlalu tinggi dan terakhir pertimbangan kualitas agar terjadi proses pembelian yang stabil.

\section{DAFTAR PUSTAKA}

Jamaludin. 2007. Pengantar Desain Mebel. Kiblat. Bandung.

Kotler, Philip, 1997. Marketing Management: Analysis, Planning, Implementation, and Control, 9th Ed., Englewood Cliffs, NJ: Prentice Hall, Inc.

Saputra dan Suprihadi. 2013.Pengaruh Bauran Pemasaran Terhadap Keputusan Pembelian Pada Pt. Aneka Regalindo Di Sidoarjo. Dalam Jurnal Ilmu \& Riset Manajemen 2 (10). Sekolah Tinggi Ilmu Ekonomi Indonesia (Stiesia) Surabaya. Surabaya.

Schifman, L. dan L.L. Kanuk. 2002. Perilaku Konsumen. Edisi ke-7. PT. Indeks. Jakarta.

Sumarwan, U. 2004. Perilaku Konsumen. Ghalia Indonesia. Bogor. 